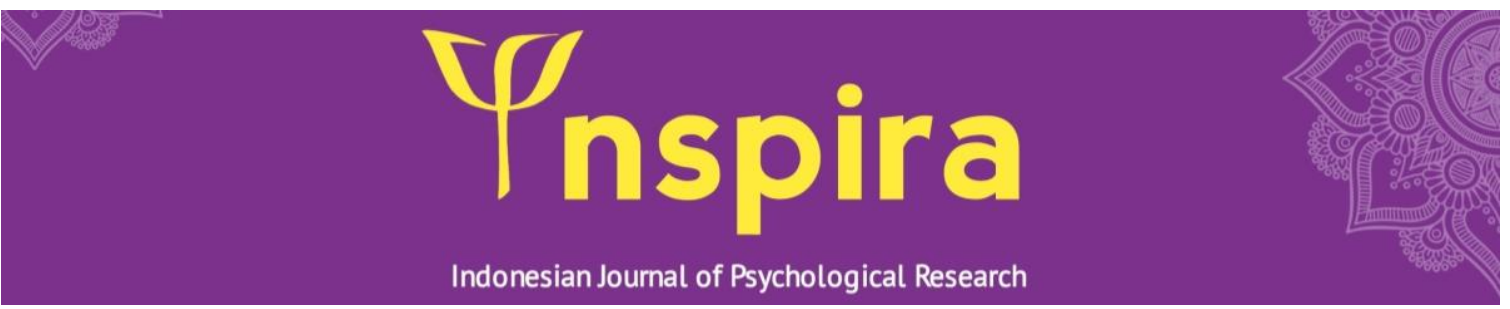

\title{
Effectiveness of social support with adolescent's self-acceptance in post- divorce parents
}

Merri Hafni ${ }^{\boxplus}$

Department of Psychology, Universitas Medan Area, North Sumatera, Indonesia.

\section{${ }^{\otimes}$ Corresponding author:}

Merri Hafni (email: hafnimerri@staff.uma.ac.id)

Abstract - The study aims to identify the effectiveness of social support to self-acceptance in adolescent post-divorce parents. The samples in this study were 40 students of SMA Al-Ulum Medan. The technique of sampling data was to use purposive sampling taken using the criteria of adolescents who are divorced parents and obtained from documentation from the school. The data collection method was the Social Support Scale and the SelfAcceptance Scale. Analyze the data using Product Moment correlation. The findings showed a significant association between social support and self-acceptance, with the coefficient is 0.875 and $\mathrm{p}$-value $<0.001$. The results showed that social support contributes to self-acceptance in $76.3 \%$. That was, there were still $23.7 \%$ of other factors not studied in this study. The results showed that social support strongly influenced adolescents to accept their parents' divorce conditions.

\section{Article History:}

Received: August 9, 2020

Revised: September 5, 2020

Accepted: November 5, 2020

Published: December 28, 2020

\section{Keyword:}

adolescent; post-divorce; selfacceptance; social support

How to cite (APA $7^{\text {th }}$ Edition)

Hafni, M. (2020). Effectiveness of social support with adolescent's self-acceptance in post-divorce parents. INSPIRA: Indonesian Journal of Psychological Research, 1(2), 38-42. https://doi.org/10.32505/inspira.v1i2.2838 


\section{INTRODUCTION}

Family is the first and foremost institution for children; the role of parents is perfect for supporting the child's future. Especially the role of a good mother to educate children, in the family we can know life. Not to be also missed from the part of a father who can help form the personality of the child. From the parenting pattern received by the child, the child can interpret their own lives and fulfil life in both physical and psychic form. Family is also a medium for us to be happy with a whole and prosperous family can make life feel pleased while on the contrary, if the family is less harmonious, there is no happiness. Father and mother must always support the opportunities children provide to build their soul and mentality for their future. A child needs the role of parents, and parents must also be able to balance their affection and work in the family.

According to Cole in Ghufron \& Risnawati S. (2014), the impact of divorce with low selfacceptance is to feel neglected by parents who leave it, having difficulty in accepting reality in the aftermath of divorce, withdrawing from old friends and his favourite activities, losing interest in learning, performing unworkable or unacceptable acts such as stealing, ditching, in addition to starting to use abusive language, being aggressive or rebellious, feeling angry and unsure of his own beliefs regarding love, marriage and family, began to worry about adult issues, such as family financial security, felt obliged to bear more adult responsibilities in the family

Self-acceptance, according to Hurlock (in Hadyani \& Indriana, 2017), defines selfacceptance as the ability to accept everything that is in oneself both lack and excess, so that if there is an unpleasant event, one will be able to think logically about the good or bad of a problem that occurs without causing hostility, feelings, or feelings of inferiority, shame and insecurity.

Hurlock (1991) added that it is not impossible to arise a lame personality if the individual sees only from one side. The more the individual likes himself, he will accept himself, and he will be more accepted by others who say that individuals with good self-acceptance will be able to get natural characters and not criticize something that cannot be changed anymore.

Several factors certainly influence one's self-acceptance. According to Sari \& Nuryoto (2017), one of the factors that influence self-acceptance is social support. According to Sarason \& Pierced in Happynda (2017), social support is a physical and psychological comfort given by others. With social support, one feels that he or she is loved, cared for, and appreciated by others.

According to Gottlieb in Maslihah (2011), social support is verbal and non-verbal information, advice, real help or behaviour provided by people familiar with the subject in his social environment that positively affects the emotional state that receives such support. In this case, the person who gets social support emotionally feels relieved because he or she is noticed, gets advice, or a pleasant impression on him to find a way out to solve the problem.

Social support from the family is significant in supporting the future of adolescents after a parent's divorce. Social support from the family and the environment is very influential at the end of youth, where this social support has a positive impact. For example, if the child has no place to complain for their anger, the family or the environment is very important to vent the outpouring of hearts that want to listen. The most important social support is from parents and families. Although the family is no longer intact, teenagers need protection for both sides between mother and father. Teenagers want to be cared for, loved, loved and given the support 
that suits the growing age of adolescents. In addition to parents' approval, help from the environment is also vital, namely support from teachers, school friends, peers and neighbours. Because in adolescence, it is crucial to give them more attention than their parents, but in reality, their parents have also separated. The teenager had to accept the fact of his life.

Thus, from the phenomenon and exposure to the above theory when viewed from adolescents with divorced parents, with good social support from the family and from the outside environment, the youth will always accept themselves well if supported by social support. Therefore social support is significant for the self-acceptance of teenagers.

\section{RESEARCH METHOD}

The method in this study uses the quantitative approach, which is to suppress the analysis of numerical data processed by statistical method. Through quantitative methods, there will be significant differences between the variables studied. At the same time, the type of research used in this study is correlational that connects two variables, between self-acceptance $(Y)$ in postdivorce adolescent parents with social support variables $(\mathrm{X})$.

Social support is defined as verbal and non-verbal information, advice, real help or behaviour provided by people familiar with the subject in their social environment who positively affect the emotional state that receives the support. In this case, the person who gets social support emotionally feels relieved because he or she is noticed, gets advice, or a pleasant impression on him to find a way out to solve the problem.

Self-acceptance is the extent to which an individual can be aware of the personality characteristics they have and is willing to live with those characteristics. The ability to accept everything in oneself lacks and advantages that have, so that if there is an unpleasant event, then one will be able to think logically about the good or bad of a problem that occurs without causing hostility, inferiority, and shame and insecurity.

The population in this study was 450 students of class X-XII at SMA Al-Ulum Medan with an age range of 15-18 years. The sample in the study was 40 teenagers from divorced parents. The technique used in taking research samples is the purposive sampling technique, a sampling technique with specific criteria. The data analysis used in this study is a quantitative study with the Pearson Product Moment test. The collected data is analyzed to see the research results and then draw conclusions from the investigation results.

\section{RESULT}

Based on the test results of the measuring instrument known Social Support Scale of adolescents, out of 50 items, there are 34 valid items with a corrected item-total correlation value between 0.305 to 0.597 . The reliability index gained 0.873. While the Self-Acceptance Scale trial results, out of 50 items, there are 39 valid items with a corrected value of total correlation between 0.300 to 0.525 , and the reliability index was 0.913 .

Normality tests on data distribution are conducted to prove that the research data spreads based on the principle of standard curves. The spread normality test was analyzed using the One 
Kolmogorov-Smirnov Test. Based on the analysis, it is known that both variables follow the normal distribution that is distributed following the principle of standard curves. Table 1 is a summary of the calculation of normality of data distribution

Table 1 Normality Test Results

\begin{tabular}{cccccc}
\hline Variable & Mean & $\begin{array}{c}\text { Kolmogorov- } \\
\text { Smirnov }\end{array}$ & $\begin{array}{c}\text { Standard } \\
\text { Deviation }\end{array}$ & -value & Explanation \\
\hline $\begin{array}{c}\text { Self- } \\
\text { acceptance }\end{array}$ & 168.25 & 0.625 & 13.511 & 0.830 & Normal \\
\hline $\begin{array}{c}\text { Social } \\
\text { support }\end{array}$ & 161.75 & 0.642 & 14.569 & 0.804 & Normal \\
\hline
\end{tabular}

Based on the analysis results with the Pearson correlation analysis method, it is known that there is a positive relationship between social support and self-acceptance in post-divorce adolescent parents where $\mathrm{r}=0.873$ with $p$-value $<0.001$.

Table 2 Multiple regression tests

\begin{tabular}{ccccc}
\hline Correlation & $\mathrm{r}$ & $\mathrm{r}^{2}$ & $p$-value & Explanation \\
\hline $\mathrm{X}-\mathrm{Y}$ & 0.873 & 0.763 & $<0.001$ & Significant \\
\hline
\end{tabular}

The determinant coefficient ( $\mathrm{r} 2$ ) of the relationship between variable $\mathrm{X}$ and variable $\mathrm{Y}$ is 0.763. This distribution shows that social support contributed to self-acceptance by $76.3 \%$.

\section{DISCUSSION}

To know how the condition of social support, it is necessary to compare between empirical mean and hypothetical mean by paying attention to the magnitude of each variable. For social support variables, the value or SD is 14,569 , while the self-acceptance variable value or SD is 13,511. Based on the comparison of both mean (hypothetical and empirical mean), adolescents with high social support have the same high self-acceptance. Ahyani \& Kumalasari (2012) find this finding, which states that social support can help adolescent self-adjustment.

This means that the higher the social support, the higher the self-acceptance inflicted on adolescents with divorced parents. On the contrary, the lower the social support, the lower the self-acceptance imposed on adolescents with divorced parents.

\section{CONCLUSION}

Adolescent social support contributed $76.3 \%$ to the high low self-acceptance in postdivorce adolescents. This is seen from the determinant coefficient $=0.763$. Based on these results, it is known that there is still a $23.7 \%$ influence of other factors on self-acceptance in adolescents, where other factors include age, education, intelligence, physical state and parenting style.

\section{REFERENCES}

Ahyani, L. N. \& Kumalasari, F. (2012). Hubungan antara dukungan sosial dengan penyesuaian diri remaja di panti asuhan. Jurnal Psikologi: PITUTU, 1(1), 21-31.

Ghufron, M. N. \& Risnawati S., R. (2014). Teori-teori Psikologi. Ar-ruz Media 
Happynda, M. A. (2017). Hubungan antara dukungan sosial dengan penerimaan diri remaja dhuafa di panti asuhan. [Undergraduate thesis, Universitas Muhammadiyah Surakarta].

Hurlock, E. B. (1991). Psikologi perkembangan: Suatu pendekatan sepanjang rentang kehidupan. Erlangga

Hadyani, I. A., \& Indriana, Y. (2017). "Proses penerimaan diri terhadap perceraian orangtua. Jurnal Empati, 7(3), 303-312.

Maslihah, S. (2012). Studi tentang hubungan dukungan sosial, penyesuaian sosial di lingkungan sekolah dan prestasi akademik siswa SMPIT Assyfa Boarding School Subang Jawa Barat. Jurnal Psikologi, 10(2), 103-114. https://doi.org/10.14710/jpu.10.2.103-114. 